\title{
The Role of a Personality in Historical and Political Process
}

\section{Rola osobowości w procesach historycznych i politycznych}

\section{- Abstrakt •}

W artykule zaprezentowano analizę takich koncepcji, jak "prawidłowość historyczna”, „przypadek” oraz „wielka osobistość”. Należy podkreślić, że badając zagadnienia epistemologiczne w naukach historycznych, trzeba bazować na kategoriach systemowych należących do ogólnej metodologii naukowej, przede wszystkim na kategorii teorii naukowej. Niniejszy artykuł przedstawia rolę i miejsce osobowości w procesach historycznych i politycznych. Wykazano, że aby rozwiązać naglące problemy rozwoju społecznego, potrzeba przywódców, którzy dzięki swojej energii, woli, zaletom umysłu i umiejętnościom są w stanie wcielić w życie jakościowe zmiany.

Słowa kluczowe: historia; nauki historyczne; prawa historyczne; przypadek, osobowość; rola osobowości

\section{- Abstract •}

The article presents the analysis of such concepts as "historical regularity", "chance" and "great personality". It is stressed that while studying epistemological problems of historical science we must focus on the system categories being used in general methodology of science, first of all on the category "scientific theory". The role and place of personality in historical and political process is reviewed. It is noted that in order to solve the urgent problems of social development, there is a need for leaders who, through their own energy, will, mind and abilities, can implement quality changes.

Keywords: history; historical science; laws of history; chance; personality; role of personality

Mankind has only one history, but the past remains open for various interpretations. Every new generation understands history in its own way, and the recent history causes emerging of the enormous amount of different views and ap- 
proaches. This fact cannot be explained just by pluralism of historians' points of view, because they all are human and they can't avoid the pressure of their own emotions and feelings while witnessing different historic events. "Anyway, we should admit (since everything concerning human nature is not perfect and almost always all advantages are accompanied with some losses), that such historical works, especially if they are written at the same time that is being described and researched, are considered to be the less reliable sources, because they often contain sympathies and antipathies of the author" (Bacon, 1977). That's why the majority of academic works in the field of history were composed many centuries after those historical events had taken place. The ingenious work of English historian Edward Gibbon (1737-1794) The History of the Decline and Fall of the Roman Empire is a strong confirmation of the concept presented above. In this connection the problem presented in the title of the article is one of the most important aspects of historical and political research methodology, in particular: under which circumstances do emerge great historical personalities, what place do they have in society, what role do they play during radical social transformations?

The key principal of every fundamental science bases on the idea that it doesn't deal with accidents and chances, but researches first of all the phenomena, which repeat, as the repeatability is the main feature of consistency and regularity. By discovering regularity we discover causality, and according to this, everything that's consequential can be foreseen and predicted. "Each phenomenon in the world has its own reason. Reason is the phenomenon which goes ahead of the consequence and causes this consequence obligatorily. If we know the reasons, we can predict the consequences of those reasons" (Gorbatenko, 2006). The correctness of this idea is confirmed by the development of natural or technical sciences.

On the other hand, what is chance and does it deny causality?

To begin with of all let us present some general reflections. Firstly, we can make an assessment about an event and its accidental or consequential matter just from contemporary point of view; secondly, there is a great possibility of subjectivism present in assessments of the past because the same fact could be interpreted in different ways; thirdly, historical regularities have to be discovered and proved but chance appears to be an obvious fact; and fourthly, if we try to get a chance out of historical process, than all historical researches need great validity and proving basis.

There are a lot of definitions and interpretations of what "chance" means. Here are some of them: chance is a certain coincidence of facts, which are not related to each other the way reason and consequence are and don't depend on any mutual cause, which don't have any necessary connection (Windelband); chance is coin- 
cidence of current facts independent from one another, or coincidence of known complex of individual reasons with known complex of general reasons (Kaufmann). We would not deny our own subjectivism and would like to suggest a definition that, in our opinion, reveals the essence of chance as a phenomenon the best way. According to probability theory, chance is a certain event and its existence or happening can't be predicted on the ground of current causes, and the problem is not that we deny any existence of causal connections, but it is that such connections can't be known or they are so complicated and we can't go any further.

So as it was mentioned above, there is no problem in finding and defying regularities in natural sciences, but what about social sciences and are there objective laws of history, by understanding which we could easily predict our future? This question caused discussions among many generations of scientists and philosophers, because the variability of historical regularities often leads to skeptical attitude towards them at all. There are some issues that must be clarified, because the concept "history" is usually understood differently (high-grade science; applied discipline, which borrows theoretical issues from other sciences; empirical discipline, that exists without any theoretical basis; half-science and half-art and so on); the same thing is with the notion "laws of history", which is nowadays understood differently comparing to the past centuries. Cicero once described "laws of history" like this: "... who is unaware of the first law of history, which is not to tell any lies, and then - not to cover any truth, and so there shouldn't be any suspicion that the author is rather favorable or hostile to someone he is writing about" (Utchenko, 1986). Some authors not only don't accept the existence of historical regularities, but also deny them completely. For instance Oswald Spengler (1880-1936) stood for this approach. He claimed that a real science is possible just in the field of studying nature, while history, being far from nature, is also far from science. "Here we have to admit" - Oswald Spengler wrote in his famous The Decline of the West - "that there is no specific historical way of research. The thing we usually call this name, borrows its methods almost exceptionally from physics - the field of knowledge in which those methods were strictly elaborated. People usually search for connections, causes and consequences in different phenomena, calling it: providing historical research" (Spengler, 2000).

At first glance, the answer to the question, presented above, must be simple. If we admit that history is a science - then yes: laws of history do exist; if we don't then we can hold a discussion. The logic here is simple and clear: the main task of any science is discovering the laws. History is also a science and this means that discovering laws of history is its duty. The only thing remaining is just a detail to call those laws by name. In fact, historians are demanded to do much more, 
which is to make an analysis of all known phenomena and to explain them, and that exactly what no one has ever done. And even more, we must admit, that writing history is a creative process, sometimes having much in common with writing a historical novel. "I doubt if there is a novelist or a historian, who could avoid metaphysical exaggerations while speaking about small reasons causing great consequences. Because exploring the depth of history or the mysteries of human soul, sometimes you are wondering with horror how easy it comes that any inconspicuous event could lead to a catastrophe for a single person or even for the whole state.... For some people see a game of chance in the bizarre way of events, but others see there a wise interference of the hand of God..." (Dumas, 2004).

We can discuss about the time when historical knowledge has become a science - at the second half of the $18^{\text {th }}$ century or already in the $19^{\text {th }}$ century. It is important that since the second half of the $18^{\text {th }}$ century philosophy of history evolved very intensively, and the problem of existence of objective laws of history was researched within its framework. At the same time we should note that the notion "philosophy of history" has different interpretations in scientific literature. For example, English historian and philosopher R.G. Collingwood (1889-1943) gives four versions of interpretation of above-mentioned notion: firstly, (according to Voltaire) philosophy of history is a "critical historiography"; secondly, (according to Hegel) philosophy of history is a philosophical interpretation of World History; thirdly, (according to the positivists) the main duty of philosophy of history is to discover general laws of social evolution; and fourthly, philosophy of history is understood as doctrine about historical knowledge. In the framework of philosophy of history there are theories that directly or indirectly recognize the existence of causality of historical process and there are such that deny any causality or any possibility to study it. The final answer to this question could be given by the historical science itself right after it discovers such laws and showcases their functioning on the example of empirical data, or, otherwise after historical science proves that those laws don't exist. Right now we can state that no one has managed to elaborate a general historical law on the basis of complicated historical realities, and the matter here has nothing to do with lack of talents of those who tried.

It is well-known that even today the large scale of approaches and methodological backgrounds cause a lot of discussions. And even more, the process of scientific specialization has led to more diversity in thoughts and views. Historians, philosophers, political scientists and sociologists consider and research the past from their own points of view, creating their own instruments and methodology, elaborating different types and mechanisms of regularities, losing wherein the main thing - integrity. It is absolutely obvious that modern historical science 
needs first of all an elaboration of the methods of united approach to understand society and its development, logical comprehension, search for common regularities, because without everything mentioned above, history just looks like a chaotic summary of different events and facts. We are convinced that it is necessary to study epistemological problems of historical science relying on the same categorical system, which is used in the general methodology of science and has a category of "scientific theory" as basic.

The study of regularities promotes understanding the integrity of historical process, but the place and role of regularities and chances in lives of concrete people are also of a great interest to researches. Studying history we can't restrict the area of research just by facts, because history first of all is a story of human life and it doesn't exist beside human mind. History without conscience, without human psychology and human mind can't be real history any more it rather could be called a physics of human being. For instance, human behavior in times of famines, holocausts, repressions can be easily predicted. This behavior really has its own regularities, though in this case not laws of history but laws of nature do act.

Once in western scientific literature there were some widely spread views and conceptions that exaggerated the role of human factor and free will in historical process. In history of philosophy the problems of choice as an act of will and selfrealization of human being were widely researched. Recognizing a human being as a personality that is aware of the responsibility for his/her own life, well-known representatives of world philosophy stressed that choice, which is objectivized in in decisions and acts, is the most important indication of personal freedom.

So, emerging of outstanding personalities, whose activities and creations are to be memorized through centuries, is a natural process. But the question remains, if such people appeared in the pages of history by chance.

To begin with, let us note that all philosophical theories recognize in some way the existence of influence of a personality on the historical process, but the place and role of personalities in society is understood in many different ways. The authors dealing with the problems of human personality, usually base on the concept that objective social needs, goals and perspectives of human development are functioning, first of all, as individual needs and interests of each person. In such a complicated dialectical process the activity of personality emerges as general regularity. This point leaves a question about the role of a personality open, because if we admit that World History is just "biography of great people" (T. Carlyle), then we easily could make a step towards an average voluntarism and claim that great personalities, due to their wisdom, will and character, etc are able to change history and defy great epochs. It is hard to agree with such a claim. If certain society 
doesn't have all needed preconditions and backgrounds for fundamental changes, then even a genius can't cause them. Charles Luis de Montesquieu (1689-1755) in his work Considerations on the Causes of the Greatness of the Romans and their Decline stressed that all chances are subject to general causes: "Fortune doesn't rule the word; the Romans are the proof of this idea, for their businesses were always successful when they were managed according to an accountable plan but they began to lose while doing another way. There are general causes of both moral and physical matter that act in every monarchy and can exalt it, support or overthrow it; all chances are subject to these causes. If just one accidentally lost battle i.e. one separate cause has ruined a state, it means, that there was a general cause, which led to ruining of this state due to one lost battle. To cut a long story short, all separated causes depend on some common ground" (Montesquieu, 1955).

Voltaire (1694-1779) had the same opinion: "Chance is a senseless word; nothing can exist without cause. The world is established according to the laws of mathematics and it means that it was established of reason" (Voltaire, 1989). Besides, we read in a work of well-known German thinker J.G. Herder (1744-1903): "no historical event happens separately; each event has its roots in present causes, in the spirit of times and nations; an event is just a clock face, but the clock hand is moved by hidden weights" (Herder, 1977).

Here is the quote from French sociologist Gustave Le Bon about the role of great people in civilization development: "The study of civilizations shows that we owe all successes to a very small group of people... They are a real glory of the nation, and each society member including the lowest one can be proud of them. They don't appear occasionally or by chance but they are the result of long past and concentrate in themselves the greatness of their time and race... In politics real great people are those, who are able to foresee the emerging demands, events that were prepared in the past, and show the best way to keep on" (Le Bon, 2010). In other pages we can read the following: "The role of all great leaders consists mainly in creating a belief both religious and political, or a belief in a business or idea, and that's why their influence is very strong" (Le Bon, 2010).

The world history shows us the examples of how the will of one person could change the life and destiny of the whole state. Maybe, we don't know much the real state of affairs and can't objectively assess the events of distant past but the example following below makes us take a thought... ("We are presenting this example as a fact leaving purposely all the questions about reasons, causes and motives for future discussions"). At one time a Roman historian from the $1^{\text {st }}$ century BC Cornelius Nepos mentioned a commander from Thebes Epaminondas in his work known for us by name About Great People. "Finishing the story about his 
virtues and his life, I would add just one thing that everyone agrees with: before Epaminondas was born and after his death the city of Thebes was under the rule of strangers, and otherwise - when he ruled his fellow citizens Thebes was the greatest city in Greece. Here we can make a conclusion that just one person was of greater importance than the whole state" (Nepos Cornelius, 1992).

An interconnection between personality and chance rarely appears to be equivalent. Usually one side has a dominant position: it is personal side if we talk about really great people in history, and it is accidental side if we talk about people who under certain circumstances could get into history. It is very important for any historian to keep his/her rational thinking because if we accept that even insignificant events can cause global historical changes then it is easy to come to idea that even very small chances can dramatically influence the world history.

To confirm the ideas presented above let us give just one example. This happened to the count Wilhelm II of Holland who intended to become the Emperor of the Holy Roman Empire but one accident prevented him. "In January 1256 he was turning back home to Holland to solve one local problem in Frisia before he would have been crowned in Rome. But the crack in ice put an end on his future brilliant career, because the count's horse as well as he himself dressed in armor drowned instantly" (Davis, 2008).

And now we can guess what could happen if he hadn't drowned or if the ice had been stronger, or if it had been summer and so on. Let's just say that in this case the variations of understanding history may be endless.

In conclusions let's memorize the idea of another outstanding person: "The world consists of necessity and chances: human mind stands between them and can operate with both of them; it considers necessity to be the basis of its existence; it is able to fix, to direct and to take advantage of chances; and just the person whose mind is firm and unwavering deserves to be called god on the Earth" (Goethe, 1978). The ideas of genius Goethe (1749-1832) are relevant and topical. The real personality will always face the problem of choice.

And finally, the history claims that there is a demand for leaders capable of solving main social development problems and of fostering changes due to their own energy, creative mind and talents. We would like to believe that in this hard time for our country such personality will emerge and realize him/herself. 


\section{References:}

Bacon, F. (1977). Sochineniya v dvuh tomah. Vol.1. Moskva: Mysl'.

Davis, N. (2008). Yevropa: Istoriya. Kïv: Vydavnytstvo Solomiyi Padlychko Osnovy.

Dumas, A. (2004). Isabella Bavarskaya: Roman. Moskva: Izdatelstvo ACT.

Goethe, J.W. (1978). Sobraniye sochineniy v 10-ti tomah. Vol. 7. Moskva: Izdatelstvo Hudozh.literanura.

Gorbatenko, V.P. (2006). Politychne prognozuvannya: Teoriya, methodologiya, praktyka. Kiï: Genesa.

Herder, J.G. (1977). Idei k filosofiyi istoriyi chelovechestva. Moskva: Izdatelstvo Nauka.

Le Bon, G. (2010). Psihologiya narodov i mass. Chelyabinsk: Sotsium.

Montesquieu de, Ch.L. (1955). Izbrannyey proizvedeniye. Moskva: Gosudarstvennoye izdatelstvo politicheskoy literatury.

Nepos C. (1992). O znamenityh inozemnyh polkovodtsah. Iz knigi o rimskih istorikah. Moskva: Izdatelstvo MGU.

Spengler, O. (2000). Zakat Yevropy. Minsk: Harvest, Moskva: Izdatelstvo ACT.

Utchenko, S.L. (1986). Cicero i yego vremya. Moskva: Mysl'.

Voltaire. (1989). Filosofskiye sochineniya. Moskva: Izdatelstvo Nauka. 